4

\title{
Seasonal variability of crustal and marine trace elements in the aerosol at Neumayer Station, Antarctica
}

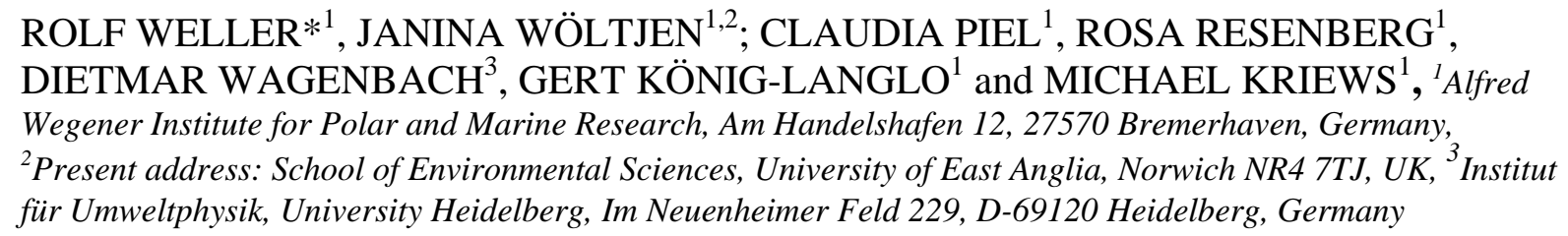

* Correponding author.

e-mail: Rolf.Weller@awi.de 


\section{ABSTRACT} Atmospheric trace element concentrations were measured from March 1999 through December 2003 at the Air Chemistry Observatory of the German Antarctic station Neumayer by inductively coupled plasma - quadrupol mass spectrometry (ICP-QMS) and ion chromatography (IC). This continuous five year long record derived from weekly aerosol sampling revealed a distinct seasonal summer maximum for elements linked with mineral dust entry (Al, $\mathrm{La}, \mathrm{Ce}, \mathrm{Nd}$ ) and a winter maximum for the mostly sea salt derived elements $\mathrm{Li}, \mathrm{Na}, \mathrm{K}, \mathrm{Mg}$, Ca, and Sr. The relative seasonal amplitude was around 1.7 and 1.4 for mineral dust (La) and sea salt aerosol $(\mathrm{Na})$, respectively. On average a significant deviation regarding mean ocean water composition was apparent for $\mathrm{Li}, \mathrm{Mg}$, and $\mathrm{Sr}$ which could hardly be explained by mirabilite precipitation on freshly formed sea ice. In addition we observed all over the year a not clarified high variability of element ratios $\mathrm{Li} / \mathrm{Na}, \mathrm{K} / \mathrm{Na}, \mathrm{Mg} / \mathrm{Na}, \mathrm{Ca} / \mathrm{Na}$, and $\mathrm{Sr} / \mathrm{Na}$. We found an intriguing co-variation of Se concentrations with biogenic sulfur aerosols (methane sul-

66 fonate and non-sea salt sulfate), indicating a dominant marine biogenic source for this element linked with the marine biogenic sulfur source. 


\section{Introduction}

The nearly completely ice covered Antarctic continent is virtually free of primary and secondary aerosol sources while the Southern Ocean is by far the dominant source to the Antarctic aerosol body making atmospheric sea salt and biogenic sulfur the major aerosol components (Wagenbach et al., 1998; Minikin et al., 1998). Terrestrial sources are limited to some insular rocky regions (on the Antarctic peninsula, in the coastal dry valleys and on high mountain ranges) and volcanic activity of Mt. Erebus. Nowadays, minor anthropogenic emissions arising from fossil fuel combustion during research and tourism activities may be considered as well. On the whole these natural and anthropogenic sources constitute local or regional trace element emissions of mineral dust, sulfur, and specific heavy metals which are thought to be of minor importance for the overall aerosol budget of Antarctica. Therefore, Antarctica offers an outstanding place to study the background composition and the natural biogeochemical cycling of aerosol.

Apart from ion analyses, only limited trace element measurements have been conducted so far in Antarctic aerosol samples as: at South Pole (Zoller et al., 1974; Cunningham and Zoller, 1981; Tuncel et al., 1989), at the Antarctic peninsula (Dick, 1991; Artaxo et al., 1992) and at coastal areas (i.e. Neumayer Station, Görlach, (1988) and Wagenbach et al. (1988)). In recent years the need for long term background aerosol studies, especially addressing the trace element composition, has been recognized. Certain heavy metals (e.g. Pb, Cd, Cr) can be employed as valuable tracers for the growing impact of anthropogenic heavy metal emissions for remote Antarctica (Wolff and Suttie, 1994; Wolff et al., 1999; Planchon et al., 2002). Furthermore, mineral dust derived trace elements like Fe may act as micronutrients affecting the biological activity of the ocean (Jickells et al., 2005), e.g. the atmospheric $\mathrm{CO}_{2}$ burial (Bopp et al., 2003; Wolff et al., 2006) and the emission of dimethyl sulfide (DMS) (Turner et al., 2004), which is globally the most important precursor for natural sulfate aerosol. Finally, 
mineral dust and sea salt profiles retrieved from polar ice cores have proven to provide a wealth of paleoclimatic information (e.g. Petit et al., 1999; Wolff et al., 2006; Fischer et al., 2007; Ruth et al., 2007). For improving the interpretation of these records, a better knowledge about long range transported continental dust and regional derived sea salt would be needed, especially including the seasonality of their atmospheric loading and entry into the Antarctic continent. Concerning sea salt aerosol, the formation on freshly formed sea ice, associated with a significant sea salt fractionation, has been put forward as an alternative source (Rankin et al., 2000 and 2002; Wolff et al., 2003) to the accepted process by wind induced bubble bursting over open ocean water (Monahan et al., 1986). If the significance of this source proves true, it would entail a paradigm shift in the interpretation of sea salt profiles from polar ice cores (Wolff et al., 2003).

Here, we present atmospheric trace element records mainly associated with mineral dust and marine sources which are continuously observed between 1999-2003 at the German Antarctic Neumayer Station. Primarily focusing on seasonal aspects, the weekly filter samples were analysed by ICP-QMS for the trace element $\mathrm{Li}, \mathrm{Na}, \mathrm{K}, \mathrm{Mg}, \mathrm{Ca}, \mathrm{Sr}, \mathrm{Al}, \mathrm{La}, \mathrm{Ce}, \mathrm{Nd}$, and Se. The ICP-QMS results are supported by our regular IC analyses providing complementary information on the ionic aerosol composition with respect to methane sulfonate, sulfate, $\mathrm{Na}^{+}$, $\mathrm{NH}_{4}^{+}, \mathrm{K}^{+}, \mathrm{Mg}^{2+}$, and $\mathrm{Ca}^{2+}$.

\section{Methods}

\subsection{Measurement Site and Meteorological Conditions}

Aerosol sampling was made at the Air Chemistry Observatory, about $1.5 \mathrm{~km}$ south of Neumayer station $\left(70^{\circ} 39^{\prime} \mathrm{S}, 8^{\circ} 15^{\prime} \mathrm{W}\right)$. During the summer months, the bay and the nearby ice edge are mainly free of sea ice and there is always open water present. Apart from a few nunataks about $100 \mathrm{~km}$ south of the station there are no ice-free land surfaces near Neumayer, 
119 and the probability of contact with air masses from ice-free continents is small. In general

120 there are two different wind regimes: (1) Strong synoptically affected winds are from the East

121 with infrequent geostrophically intensified switches to the West and (2) weak katabatic winds

122 from southern directions. The air mass transport pattern to Neumayer Station was investigated

123 by Kottmeier and Fay (1998) and a more detailed picture on the climatology at Neumayer

124 Station can be found in König-Langlo et al. (1998).

125 Aerosol was collected on Whatman 541 cellulose filters which were precleaned by soaking

126 in $\mathrm{HCl}$ followed by rinsing with de-ionize water until virtually no enhancement of the electro-

127 lytical conductivity could be detected. The aerosol was continuously sampled at $120 \mathrm{~m}^{3} \mathrm{~h}^{-1}$

128 by two filters (diameter $240 \mathrm{~mm}$ ) in series using a ventilated electropolished stainless steel

129 inlet stack (total height about $8 \mathrm{~m}$ above the snow surface) with a 50\% aerodynamic cut-off

130 diameter around 7-10 $\mu \mathrm{m}$ at wind velocities between $4-10 \mathrm{~m} \mathrm{~s}^{-1}$. This high volume sampling

131 technique is part of the continuous long-term observation programme carried out since 1983

132 at Neumayer. Here we refer to samples taken from March 1999 through December 2003.

133 These data were based on a sampling period of typically 7 days which corresponds to a probe

134 volume of around $2 \times 10^{4} \mathrm{~m}^{3}$ STP. A more detailed description of the sampling procedure itself

135 is given in Wagenbach et al. (1988).

136 Local pollution by vehicles and the base itself is a potential problem for many measure-

137 ments concerning the background status of the Antarctic troposphere. To ensure contamina-

138 tion free air sampling, the Air Chemistry Observatory is situated in a clean air facility ap-

139 proximately $1.5 \mathrm{~km}$ south of Neumayer. Due to the fact that northerly wind directions are

140 very rare, contamination from the base can be excluded for most of the time. Additionally, the

141 power supply (20 kW) is provided by cable from the main station, thus no fuel driven genera-

142 tor is operated in the observatory vicinity. Finally, contamination-free sampling is controlled

143 by the permanently recorded wind velocity, wind direction and by the condensation particle 
144 (CP) concentration. Contamination was indicated for each of the following criteria: Wind 145 direction within a $330^{\circ}-30^{\circ}$ sector, wind velocity $<2.0 \mathrm{~m} \mathrm{~s}^{-1}$ and/or CP concentrations (meas146 ured by a TSI CPC 3022A particle counter) $>2500 \mathrm{~cm}^{-3}$ during summer, $>800 \mathrm{~cm}^{-3}$ during

147 spring/autumn and $>400 \mathrm{~cm}^{-3}$ during winter. The CP threshold values were chosen based on 148 our more than 20-year long CP record from Neumayer, demonstrating that CP concentrations 149 above the corresponding levels can usually be traced back to local pollution. In case of con150 tamination, given by these criteria, an automatic interrupt of the sampling procedure was 151 initiated within one second (shut down of the pumps and closing the electromotive valves 152 typically needed around 10 seconds). Sampling was restarted after recurrence of clean air 153 conditions and a delay of two minutes. However, most of the data loss was provoked by 154 blizzards and drifting snow (wind velocity $>20 \mathrm{~m} \mathrm{~s}^{-1}$ ). During such harsh weather conditions 155 aerosol sampling has to be switched off (due to the danger of snow entering the inlet) which entailed a downtime of roughly $10 \%$ of the observation period. Note, that $<2 \%$ of data loss was actually caused by potential contamination.

\subsection{Analytical Methods}

\subsubsection{ICP-QMS Analysis}

161 Trace element analysis was performed by means of ICP-QMS (ELAN 6000, Sciex/Perkin Elmer) equipped with a cross-flow nebulizer as sample introduction system. The alignment of

163 the instrument (plasma torch, ion lens, gas flow, nebulizer) was checked and adjusted before 164 analysis by daily performance solutions containing a mixture of $10 \mathrm{ng} \mathrm{g}^{-1} \mathrm{Mg}, \mathrm{Ba}, \mathrm{Ce}, \mathrm{Pb}$, and

165 Rh. One half of each filter was used for trace element analysis, while another 1/6 of each filter was used for IC analysis (see below). For trace element analyses we chose a total digestion of

167 the samples in order to quantitatively dissolve all mineral compounds, which is not been 168 given by simple acidic $\left(\mathrm{HNO}_{3}\right)$ leaching (Lindberg and Harris, 1983; Reinhardt et al., 2003, 
169 Table 5 therein). Thus these aliquots were subject to a pressurized digestion system (DAS 170100 , Picotrace) at $200^{\circ} \mathrm{C}$ in a mixture containing $\mathrm{HNO}_{3}$ (suprapure, 65\%, Merck, sub-boiling 171 bi-distilled), HF (suprapure, 40\%, Merck, sub-boiling bi-distilled) and $\mathrm{H}_{2} \mathrm{O}_{2}$ (suprapure, 30\%, 172 Merck). With this device a series of 24 samples could be digested in parallel. Each series 173 included one filter blank and a certified reference sample (NIST 1648 urban particulate mat174 ter). For calibration we used commercially available standard solutions $\left(10^{4} \mathrm{ppb}\right.$ multielement 175 verification standard 1 and 2, Perkin Elmer) which were generally applied in $1 \mathrm{ppb}, 10 \mathrm{ppb}$, 176 and $100 \mathrm{ppb}$ concentrations (1 ppb corresponds to $1 \mathrm{ng}$ of each element in $1 \mathrm{~g}$ solute). Each 177 sample was spiked by $10 \mathrm{ppb} \mathrm{Rh}$ as internal standard to normalize the signal intensities and 178 compensate instrumental sensitivity variations. The instrumental detection limits (IDL) were 179 derived from 60 blank solutions and correspond to three times the standard deviation (std) of 180 these blank values (Table 1). Based on the results of the NIST reference material, the retrieval 181 for each element to be discussed here was generally between $95 \%$ and $100 \%$. When analysing 182 the filter samples of the years 2002 and 2003 we were frequently faced with abnormally 183 elevated Al-blanks prohibiting further evaluation. Thus the time series of this period appeared 184 fragmentary. Due to these unexplained analytical problem, we decided to use the consistently measured La as mineral dust tracer and reference element for calculating crustal enrichment 186 factors.

187 The variability of the filter procedure blanks clearly governed the overall accuracy as well 188 as the analytical detection limits. These estimates were derived from the variation of 49 iden189 tically processed procedure blanks and include possible contributions by the previously 190 cleaned filters and any effects arising from handling and storage. We conservatively estimated 191 the method detection limits (MDL) as three times the standard deviation (std) of these overall 192 blank values (Table 1). In addition to this blank induced uncertainty, relative ICP-QMS cali193 bration errors were considered. In short, the combined uncertainty was found to be approxi- 
mately between $\pm 8 \%$ and $\pm 12 \%$ for element concentrations above three times the corresponding MDL. It increased from around $\pm(15-20) \%$ approaching 3xMDL level to roughly (+50/100)\% close to the MDL. The final atmospheric concentrations (in $\mathrm{ng} \mathrm{m}^{-3}$ or $\mathrm{pg} \mathrm{m}^{-3}$ ) were calculated from the blank corrected element amounts and the corrected sampled air volume to standard conditions (273.16 K and $1013 \mathrm{hPa})$.

\subsubsection{IC Analysis}

The extraction of the aliquots for IC analysis included soaking and shaking in $50 \mathrm{ml}$ MilliQ water, followed by ultrasonic treatment for 15 minutes. All samples were analyzed for methane sulfonate (MS), $\mathrm{Cl}^{-}, \mathrm{Br}^{-}, \mathrm{NO}_{3}{ }^{-}, \mathrm{SO}_{4}{ }^{2-}, \mathrm{Na}^{+}, \mathrm{NH}_{4}{ }^{+}, \mathrm{K}^{+}, \mathrm{Mg}^{2+}$, and $\mathrm{Ca}^{2+}$ by IC analysis. For details concerning IC set up, the determination of accuracy and detection limits see Piel (2004). Errors were determined from the blank variability, the typical IC error (calibration error and baseline noise), and the error from the sample air volume. In short, the combined uncertainty was between $\pm 5 \%$ and $\pm 11 \%$ for the components $\mathrm{MS}, \mathrm{Cl}^{-}, \mathrm{NO}_{3}{ }^{-}, \mathrm{SO}_{4}{ }^{2-}, \mathrm{Na}^{+}, \mathrm{K}^{+}$, $\mathrm{Mg}^{2+}$, and $\mathrm{Ca}^{2+}$ and approximately $\pm 27 \%$ for species $\mathrm{Br}^{-}$and $\mathrm{NH}_{4}{ }^{+}$. Non-sea salt sulfate (nss$\mathrm{SO}_{4}{ }^{2-}$ ) concentrations were calculated by subtracting the concentration of the sea salt derived sulfate from the total $\mathrm{SO}_{4}{ }^{2-}$ concentration (in $\mathrm{ng} \mathrm{g}^{-1}$ ). We used $\mathrm{Na}^{+}$as sea salt reference species and the sulfate to sodium ratio in bulk sea water of 0.252 for November to February, and due to the potential impact of sea salt fractionation by frost flower formation a factor of 0.07 for winter (March - October) samples (Wagenbach et al., 1998). Note that with our sampling technique, gaseous $\mathrm{HCl}, \mathrm{HBr}, \mathrm{HNO}_{3}$, and $\mathrm{NH}_{3}$ were partly collected on the filter material and contributed to the reported $\mathrm{Cl}^{-}, \mathrm{Br}^{-}, \mathrm{NO}_{3}{ }^{-}$, and $\mathrm{NH}_{4}{ }^{+}$concentrations.

For the elements $\mathrm{Na}, \mathrm{K}, \mathrm{Mg}$, and $\mathrm{Ca}$ an inter-comparison with the corresponding concentrations measured by IC was possible. A reduced major axis regression (RMA) revealed a good agreement between ICP-QMS and IC for $\mathrm{Na}$ and Mg, while the ICP-QMS systematically 
provided higher $\mathrm{K}$ and lower Ca concentrations (Table 2). For these two elements the results from the IC-analytics were used throughout the paper because they appeared more reliable. Apart from known problems associated with the detection of K and Ca by ICP-QMS (mainly interferences from Ar carrier gas of the plasma), a possible explanation in case of Ca may be the formation of hardly soluble $\mathrm{CaF}_{2}$ during digestion. The relatively high scatter of the data around the regression line, expressed by somewhat low regression coefficients $r^{2}$ (Table 2), may partly be due to the fact that ICP-QMS and IC analyses were performed with different aliquots of the corresponding filters.

\section{Results and Discussion}

\subsection{Classification of Trace Elements}

We first calculated for each element $\mathrm{M}$ the so-called crustal $\mathrm{EF}_{\text {crust }}$ and sea salt $\mathrm{EF}_{\mathrm{ss}}$ enrichment factors, respectively as:

$$
\mathrm{EF}_{\text {crust }}=\frac{(\mathrm{M} / \mathrm{La})_{\mathrm{aerosol}}}{(\mathrm{M} / \mathrm{La})_{\mathrm{crust}}}, \quad \quad \mathrm{EF}_{\mathrm{ss}}=\frac{(\mathrm{M} / \mathrm{Na})_{\mathrm{aerosol}}}{(\mathrm{M} / \mathrm{Na})_{\mathrm{ss}}}
$$

234 For reasons discussed in the analytical section, we chose as marker for mineral dust La and 235 refer to the crustal composition reported in Wedepohl (1995). Note that at Neumayer Ca is 236 largely sea salt derived (see below) and thus an unfavourable tracer for mineral dust. For the 237 corresponding $\mathrm{EF}_{\mathrm{ss}}$ we rely on standard mean ocean composition reported in Holland (1993). 238 In Fig. 1 the results are presented for winter and summer. Because the ocean is well mixed, 239 even small deviations from the standard mean ocean composition indicate that either the 240 given component was only partially associated with sea salt or a sea salt fractionation during 241 aerosol formation/transport occurred. The situation is intrinsically much more complicated in 242 case of mineral dust. First of all the crustal composition of the earth exhibits a pronounced 
variability (Wedepohl, 1995). Apart from this, weathering and mineral dust generating processes usually entail a distinct fractionation. Also the crustal element composition may significantly differ between mean crust, soil and the small (clay) particles being readily long range transported. Here, we conservatively assume that $\mathrm{EF}_{\text {crust }}$ values above 10 point at a negligible mineral dust source. The enrichment factors indicate crustal material as the main source for the elements $\mathrm{Al}, \mathrm{Nd}$, and $\mathrm{Ce}$, while, on the other hand, $\mathrm{Li}, \mathrm{K}, \mathrm{Mg}, \mathrm{Ca}$, and $\mathrm{Sr}$ were primarily sea salt derived elements, though this dissection appears equivocal for Li. Selenium in contrast was found to be highly enriched relative to crust, but also with respect to (sea salt) $\mathrm{Na}$ pointing to anthropogenic or biogenic sources.

\subsection{Overview on the Trace Element Concentrations measured at Neumayer Station}

Table 3 gives a compendium of the trace element concentrations measured five years at

Neumayer Station. In addition individual time series of trace elements representative for sea salt aerosol (Li, Na, Sr) and mineral dust (Al, La, Ce, Nd) species are presented in Figures 2 and 3. Generally, trace element concentrations at Neumayer exhibited a striking inter-annual 258 and seasonal variability. Apart from the general sparseness of data available from other Ant259 arctic sites, the intrinsic strong variability makes a coherent assessment of the inter-site differences a difficult task. Especially the extraordinarily high atmospheric Se and Al levels reported by Artaxo et al. (1992) remain unexplained (Table 4).

Görlach (1988) used acid extractable Mn and Wagenbach (1996) combined $\mathrm{Mn}$ and $\mathrm{Al}$ as 263 mineral dust proxy at Neumayer. Converting the reported Mn from Görlach (1988) into corre264 sponding La concentrations (using a mean crust composition given in Wedepohl (1995), i.e. $\mathrm{Mn} / \mathrm{La}=23.9$ ) resulted in a summer maximum of around $1.1 \mathrm{pg} \mathrm{m}^{-3}$ and a winter minimum of $0.21 \mathrm{pg} \mathrm{m}^{-3}$. This is systematically lower (by $0.21 \mathrm{pg} \mathrm{m}^{-3}$ and $0.35 \mathrm{pg} \mathrm{m}^{-3}$, respectively) but 267 still in fair agreement with our La results (Table 3). A pronounced seasonal Al (i.e. mineral 
dust) maximum during austral summer was evident at all sites, with a mineral dust entry tentatively higher at coastal Neumayer compared to continental South Pole (Table 4). The data from the Antarctic Peninsula tip appeared contradicting, and the mentioned outstanding high Al values reported by Artaxo et al. (1992) might most probably be caused by sporadic local dust production from the rocky adjacencies. In contrast to the observed marginal gradient from coastal to continental Antarctica for mineral dust related trace elements, Na (i.e. sea salt) concentrations were about an order of magnitude higher at coastal sites.

\subsection{Seasonal Aspects}

\subsubsection{Synopsis of the seasonality of the aerosol budget at Neumayer}

In order to assess the relative composition of the aerosol (by mass) and its seasonality, we included the relevant ionic compounds. Therefore we considered the aerosol compounds sea salt (calculated from the measured $\mathrm{Na}$ ) mineral dust (calculated from the measured La) and further MS, nss- $\mathrm{SO}_{4}{ }^{2-}, \mathrm{Cl}^{-}, \mathrm{NO}_{3}{ }^{-}$, and $\mathrm{NH}_{4}{ }^{+}$from the IC analyses. Clearly, the aerosol at Neumayer was dominated by sea salt particles (Fig. 4), even during summer when biogenic sulfur emissions reach their distinct annual maximum (Minikin et al., 1998), while mineral dust was generally a minor compound with a maximum mass fraction of about $5 \%$ during summer. Figure 5 shows in more detail the annual cycle of the compounds sea salt, mineral dust and biogenic sulfur (sum of MS and nss-SO ${ }_{4}{ }^{2-}$ ). In terms of aerosol composition (biogenic, sea salt, and mineral dust) the polar winter seemed confined between April and end October with the turn of the seasons occurring in March/April and October/November.

\subsubsection{Seasonality of mineral dust and sea salt entry at Neumayer}

Figures 2 and 3 indicate that mineral dust and sea salt derived trace elements (Al, La, Ce, $\mathrm{Nd}$, and $\mathrm{Li}, \mathrm{Na}, \mathrm{K}, \mathrm{Mg}, \mathrm{Ca}, \mathrm{Sr}$, respectively) were characterized by distinct mean annual 
cycles. In Figure 6 the mean seasonal cycle of the crustal and sea salt reference are displayed in monthly concentrations ( \pm standard deviation). The seasonality was most pronounced for 295 the crustal elements with a distinct concentration maximum from October through March, while for sea salt aerosol a broad maximum between April and September was evident. The mean relative seasonal amplitude, i.e. the mean maximum normalized to the corresponding 298 annual mean, was around 1.7 and 1.4 for mineral dust (La) and sea salt aerosol (Na), respec299 tively. In addition, enrichment factors also exhibited a distinct seasonality, with higher $\mathrm{EF}_{\text {crust }}$ 300 but lower $\mathrm{EF}_{\mathrm{ss}}$ in winter and vice versa (Figure 1). A possible reason for this finding might be 301 the seasonality of dust and sea salt entry observed at Neumayer. During the seasonal maximum of atmospheric dust entry in summer and sea salt concentrations in winter, the corre303 sponding enrichment factors were lowest due to the dilution of a given enrichment effect by 304 enhanced crustal dust or sea salt material, repectively.

305 The observed seasonality for mineral dust appeared consistent with previous studies from 306 Neumayer (Görlach, 1988; Wagenbach et al., 1988, Wagenbach, 1996), as well as South Pole 307 (Cunningham and Zoller, 1981; Tuncel et al., 1989), where Mn and Al was used as tracer for 308 mineral dust, respectively. A thorough evaluation of sea salt aerosol concentrations measured 309 at various coastal stations was given in Wagenbach et al. (1998). In agreement with our find310 ings, these authors reported a broad Na maximum during winter at Neumayer, which has also 311 been observed at South Pole (Tuncel et al., 1989). In general, an annual cycle of aerosol 312 components observed at remote, source free sites can be attributed to a combination in the 313 seasonality of the source strength and atmospheric transport processes. While for sea salt 314 aerosol regional or even local sources have to be considered, the source regions for mineral 315 dust on the surrounding continents are more than $4000 \mathrm{~km}$ away and consequently long range 316 transport, most probably via the free troposphere, is decisive (Genthon, 1992; Krinner and 317 Genthon, 2003). It is believed that the main provenances for Antarctic mineral dust are the 
318 Patagonian loess regions (Smith et al., 2003). The seasonal contrast of Patagonian dust fluxes 319 seems by far not as distinct as those of the atmospheric rare earth element (equivalent to 320 mineral dust) concentrations at Neumayer, though a broad maximum between October and 321 March is discernible (Gaiero et al., 2003, Figure 14 therein). In addition to this somewhat 322 ambiguous source strength seasonality, we may expect a clear annual cycle in the atmospheric mixing height above continents (typically maximum during summer). Since long range dust transport to Antarctica is favoured via the mid troposphere, a more effective transfer of dusty boundary layer into high altitudes during the summer half year would be consistent with a Neumayer summer maximum as well. This explanation is supported by measurements of a basically similar seasonality seen at this site for the long lived ${ }^{222} \mathrm{Rn}$ decay product ${ }^{210} \mathrm{~Pb}$ 328 (Wagenbach et al., 1988), known to have a rather constant (continental) emission rate and to be less effectively washed out than the typically coarse mode mineral dust particles. Therefore the observed mineral dust maximum at Neumayer is probably a combined result of the seasonality in dust generation and the more efficient uplift of dust loaded air into the free troposphere in summer.

333 The most efficient global mechanism producing sea salt aerosol is bubble bursting during whitecap formation and dispersion of wave crests by surface winds over open ocean waters 335 (Monahan et al., 1986). Thus, sea salt production exhibits a strong dependency on wind speed 336 (Fitzgerald, 1991). Compatible with this perception is the fact that storminess and wind veloc337 ity exhibit a broad maximum during the winter months at Neumayer (Fig. 7). However, as for 338 the individual data points there was virtually no correlation between wind velocity and ob339 served Na concentrations $\left(r^{2}=0.07\right)$. Note that this was also true for our low volume aerosol 340 samples taken at daily resolution between October 2003 and February 2007 (teflon-nylon 341 filter combinations, analysed by IC). It seems that the general weather situation over the 342 South Atlantic was decisive and the most efficient sea salt production occurred during passing 
343 cyclones (Wyputta, 1997). However, the sea salt aerosol loading at Neumayer should also 344 depend on the efficiency of the transport process, removal by wet deposition, and the actual 345 sea-ice cover. The interplay of these factors may have blurred a simple correlation with the 346 local wind speed. In this regard, however, we have to bear in mind that particles above an 347 aerodynamic diameter of around 7-10 $\mu$ m, which may constitute a significant if not dominant 348 fraction of the sea salt aerosol mass from nearby sources, were not adequately sampled due to 349 the cut-off of our air inlet.

350 The formation of sea salt aerosols by frost flowers and associated processes suggested by 351 Wolff et al. (2003) should be most active between March and September, consistent with the 352 observed Na seasonality. Again it can be assumed that high wind velocities are still necessary 353 to finally create sea salt aerosols by dispersion and mobilisation of frost flowers, a process 354 which is actually not yet clarified.

\subsubsection{Sea salt fractionation}

There is some evidence that during wind induced sea salt aerosol generation over open ocean waters, a fractionation of major ions $\left(\mathrm{Na}^{+}, \mathrm{Mg}^{2+}, \mathrm{K}^{+}, \mathrm{Cl}^{-}\right.$, and $\left.\mathrm{SO}_{4}{ }^{2-}\right)$ relative to bulk seawater is negligible, except for $\mathrm{Ca}^{2+}$ which appeared significantly enriched (Keene et al., 2007). On the other hand, sea ice formation entails considerable sea salt fractionation which could influence sea salt aerosol composition if freshly formed sea ice acts as a significant source. Below $-6.3^{\circ} \mathrm{C}$ solid $\mathrm{Na}_{2} \mathrm{SO}_{4} \cdot 10 \mathrm{H}_{2} \mathrm{O}$ (mirabilite) crystallizes, followed by $\mathrm{CaSO}_{4} \cdot 2 \mathrm{H}_{2} \mathrm{O}$

363 (gypsum), and $\mathrm{NaCl} \cdot 2 \mathrm{H}_{2} \mathrm{O}$ (hydrohalite) precipitation at $-22.2^{\circ} \mathrm{C}$ and $-22.9^{\circ} \mathrm{C}$, respectively 364 (Marion and Farren, 1999). A complete mirabilite precipitation, probably the dominant fractionation process on freshly formed sea ice, would lead to a Na depletion of about $11.8 \%$ by mass. Assuming simply that no fractionation would occur for the sea salt compounds Li, K, $367 \mathrm{Mg}$, and $\mathrm{Sr}$, a corresponding increase of the enrichment factors $\mathrm{EF}_{\mathrm{ss}}$ to around 1.12 should be 
expected in sea salt aerosol for this species during winter when sea salt fractionation is most probable. In fact, Rankin et al. (2000) found $\mathrm{Mg}$ and Ca enrichment factors in frost flower samples near Halley Station $\left(\mathrm{EF}_{\mathrm{ss}}(\mathrm{Mg})=1.16\right.$, and $\left.\mathrm{EF}_{\mathrm{ss}}(\mathrm{Ca})=1.15\right)$, roughly compatible with mirabilite precipitation but indicating, if at all, a negligible gypsum precipitation. Also analy-

372 ses of individual aerosol particles sampled at the coastal Syowa Station evidenced fraction373 ated Mg-rich (and Ca-rich) sea salt particles (Hara et al., 2005).

374 Combining our ICP-QMS and IC results allows to determine sea salt fractionation for an extended number of sea-salt related trace elements. In our approach we first corrected Li, K, $\mathrm{Mg}, \mathrm{Ca}$, and Sr concentrations for the minor crustal contribution (which were generally between $1 \%$ and $8 \%$ ) to derive enrichment factors $\mathrm{EF}_{\mathrm{ss}}(\mathrm{ssM})$ exclusively for the sea salt portion of these elements. To be consistent, we generally referred ssK and ssCa values to ssNa all taken from IC analyses, while for the other elements ( $\mathrm{Li}, \mathrm{Mg}, \mathrm{Sr}$ ) we relied on the ICP-QMS results and related them to ssNa also determined by ICP-QMS. In this way we circumvent potential discrepancies caused by systematic analytical differences of both methods (see section 2.2.2).

All $\mathrm{Na}_{\mathrm{ss}}$ based $\mathrm{EF}_{\mathrm{ss}}(\mathrm{ssM})$ values were strikingly variable throughout the year and, except Ca, did not exhibit a significant seasonality as would have to be expected from a depleted ssNa reference during winter (Figure 8). It is important to note that in terms of analytical accuracy departures beyond $\pm 20 \%$ (in the worst case, at very low concentrations, beyond $387 \pm 50 \%$ ) from standard mean ocean water (SMOW) should be regarded as significant. Another, 388 but hardly conceivable reason for the scatter of $\mathrm{EF}_{\mathrm{ss}}(\mathrm{ssM})$ could be more than an order of 389 magnitude higher crustal M/La ratios ( $\mathrm{M}=\mathrm{Li}, \mathrm{Na}, \mathrm{K}, \mathrm{Mg}, \mathrm{Ca}, \mathrm{Sr})$ than reported by Wedepohl 390 (1995), which would strongly increase the crustal corrections and thus the uncertainty of the 391 calculated ratios. Concerning the medium departures of $\mathrm{EF}_{\mathrm{ss}}(\mathrm{ssM})$ from $\mathrm{SMOW}$, Figure 8 392 reveals that ssLi and ssMg were enriched by a factor 2.2 and 1.2, respectively, while ssSr was 
393

394

395

depleted throughout $\left(\mathrm{EF}_{\mathrm{ss}}(\mathrm{ssSr})=0.72\right)$. For $\mathrm{ssK}$ and ssCa the (median) deviation from SMOW was not significant, except for the winter values of ssCa $\left(\mathrm{EF}_{\mathrm{ss}}(\mathrm{ssCa})_{\text {winter }}=1.34\right)$. In double-logarithmic plots of ssM ( $\mathrm{M}=\mathrm{Li}, \mathrm{K}, \mathrm{Mg}, \mathrm{Ca}, \mathrm{Sr})$ versus the ssNa reference it becomes apparent that departures from SMOW occurred equally over the whole measured concentration range and that for ssLi, ssMg, and ssSr the data points were displaced from the SMOWline (Fig. 9). Obviously, the high variability of $\mathrm{EF}_{\mathrm{ss}}(\mathrm{ssM})$ in general, as well as the median departures from SMOW for ssLi and ssSr cannot be explained by mirabilite precipitation alone. Finally the scatter of the enrichment factors (Figures 8 and 9) were strikingly higher than the results from recent laboratory investigations on sea salt aerosol formation over a realistic air/sea interface (Keene et al., 2007). In summary, our results suggest that in the present case additional unknown fractionation processes occurred during sea salt aerosol production over the whole year at the interface air/sea or air/sea-ice or subsequently during atmospheric transport and sampling.

\subsubsection{Source and seasonality of atmospheric Se}

It is believed that natural sources like sea spray, volcanoes, and the biosphere dominate the global budget of atmospheric Se by around $60 \%$, while the remaining anthropogenic sources (basically fossil fuel combustion and mining) are mainly concentrated in the northern hemisphere (Mosher and Duce, 1987). As noted by Mosher (1986), the natural and anthropogenic Se cycles are closely linked through the biosphere. The distinct seasonal Se concentration maximum during summer observed at Neumayer suggests a potential biogenic source. Amouroux et al., (2001) have demonstrated that the production of gaseous selenium species coincided with phytoplankton blooms responsible for dimethyl sulfide (DMS) emission. It was found, that the sulfur atom in DMS can be substituted by selenium (Mosher et al., 1987; Amouroux et al., 2001). Consequently, atmospheric Se should be closely coupled to the DMS 
turnover. In fact we observed a significant correlation between Se and the end products of 419 photochemical DMS oxidation, MS and nss-SO ${ }_{4}{ }^{2-}\left(\mathrm{r}(\mathrm{MS})=0.66 ; \mathrm{r}\left(\mathrm{nss}-\mathrm{SO}_{4}{ }^{2-}\right)=0.67\right)$. The co-variation of Se and MS time series is shown in Fig. 10. Even the inter-annual variability

421 largely coincided. Atmospheric Se concentrations found at South Pole were significantly 422 lower (Table 4) but showed the same seasonality with maximum values of $8.4 \pm 1.6 \mathrm{pg} \mathrm{m}^{-3}$ 423 during summer (winter concentration: 4.8 $\pm 0.8 \mathrm{pg} \mathrm{m}^{-3}$ (Tuncel et al., 1989)), in accordance 424 with a prominent marine biogenic source which should be less discernible in continental Antarctica.

Apart from this overall consistent picture there remain several open questions. First of all, we have to consider that the sampling efficiency of total Se is not well specified. Inspecting 428 some of our Whatman 541 back-up filter showed no Se concentrations above the typical blank 429 value, in agreement with results by Mosher et al. (1987) who used Whatman 41 filters. In contrast, Mosher (1986) reported on low sampling efficiencies (65\%-45\%) for this filter type in his thesis. Apart from this, knowledge on speciation of atmospheric Se is poor. Apparently, 432 DMSe, elemental Se, as well as $\mathrm{SeO}_{2}$ can be chemically transformed into water soluble se433 lenite $\left(\mathrm{SeO}_{3}{ }^{2-}\right)$ and selenate $\left(\mathrm{SeO}_{4}{ }^{2-}\right)$ in the atmosphere (Wen and Carignan, 2007). In marine 434 environments an enrichment of Se-compounds in sub-micron aerosol particles (mainly sea 435 salt particles) was suggested (Wen and Carignan, 2007). It is not clarified to what extend volatile organic and inorganic Se species (e.g. DMSe, Se, $\mathrm{SeO}_{2}$ ) are retained and likely 437 chemically transformed on the used filter material during the typical sampling interval of 7 438 days. Another issue are considerable Se background concentrations measured during polar 439 night (at Neumayer and South Pole) when regional biogenic activity ceases. This is in contrast 440 to negligible MS concentrations generally observed during winter (Figure 10). Hence we 441 tentatively assign wintertime atmospheric Se levels at Neumayer mainly to the global back442 ground load of Se. According to Cunningham and Zoller (1981), the atmospheric load of 
443 volatile elements like As and Se at South Pole could also be influenced by volcanic emissions.

444 These authors ascribed a distinct Se peak in their time series to the explosive eruption of 445 Ngauruhoe volcano in New Zealand that happened in 1975. In our case, however, the contri446 bution of volcanic Se emissions should be, if at all, of minor importance due to the distance of 447 the sole presently active but calm volcanoes Mt. Erebus and Mt. Melbourne. Above all, the 448 observed seasonality of the Se signal at Neumayer can hardly be explained by volcanic impact 449 but might partly be responsible for background Se concentrations. Interestingly, wintertime 450 Se levels at Neumayer were about a factor of three higher compared to South Pole, where the 451 impact of Mt. Erebus should be more pronounced. For mineral dust derived trace elements 452 (Al, La) a similar but weaker gradient is apparent (Table 4), suggesting that the more pro453 nounced and deeper stable inversion layer at South Pole hampers down mixing of long range transported trace compounds. In addition further minor, yet unexplained Se sources (local contamination, still active regional biogenic emissions) possibly have to be considered at Neumayer.

\section{Conclusion}

In contrast to the ionic composition of Antarctic aerosol, corresponding continuous long term observations of atmospheric trace element concentrations are so far restricted to South Pole and Neumayer. Even from these sites, complete year round data records do not cover more than 5 years in series. Our results revealed a distinct and contrary seasonality of mineral

464 dust and sea salt load at Neumayer which, along with previous results, seems to be valid for 465 coastal as well as continental Antarctica. At coastal sites, mineral dust load appeared somewhat more pronounced. More observations from different sites are necessary to establish a 
vided that mineral dust is widely uniformly distributed in the free troposphere above Antarctica, this could give us some information on the role of the stable inversion layer, which is most pronounced in continental Antarctica, as a barrier against air mass down mixing. This would be especially interesting to scrutinize and constrain models addressing aerosol deposition in Antarctica. Another interesting point was the striking variability of the measured ssM/ssNa ratios for $\mathrm{M}=\mathrm{Li}, \mathrm{K}, \mathrm{Mg}, \mathrm{Ca}$, and $\mathrm{Sr}$, suggesting that apart from sea salt formation in sea ice covered regions itself, sea salt aerosol fractionation processes are not sufficiently clarified. As a consequence we are still lacking a tracer to reliably assess sea salt production on sea ice, a crucial point for the interpretation of sea salt records in polar ice cores. Marine biochemistry was most probably the dominant source for Se. An interesting open question is, how much Se is persistently deposited in polar snow and may serve as a proxy for biogenic activity in polar ice cores. Clearly, more investigations on the atmospheric photochemistry of marine biogenic selenium as well as the chemical nature of particulate atmospheric Se are required.

Acknowledgements. The authors would like to thank the technicians and scientists of the Neumayer overwintering crews of the years 1999-2003. Helpful comments and suggestions on the manuscript by an anonymous reviewer is greatly appreciated. This is AWI publication no. xy. Data are available from Pangaea (doi:10.1594/PANGAEA.691456). 


\section{References}

Amouroux, D., Liss, P.S., Tessier, E., Hamren-Larsson, M., and Donard, O.F.X. 2001. Role of oceans as biogenic sources of selenium. Earth Planet. Sci. Lett. 189, 277-283.

Artaxo, P., Rabello, M.L.C., Maenhaut, W., and van Grieken, R. 1992. Trace elements and 492 individual particle analyis of atmospheric aerosols from the Antrctic peninsula. Tellus 44B, $493 \quad 318-334$.

494 Bopp, L., Kohfeld, K.E., Le Quéré, C., Aumont, O. 2003. Dust impact on marine biota and 495 atmospheric $\mathrm{CO}_{2}$ during glacial periods. Paleoceanography 18(2), 496 doi:10.1029/2002PA000810.

497 Cunningham, W.C. and Zoller, W.H. 1981. The chemical composition of remote area aero498 sols. J. Aerosol Sci., 12(4), 367-384.

499 Dick, A.L. 1991. Concentrations and sources of metals in the Antarctic Peninsula aerosol. 500 Geochim. Cosmochim. Acta, 55, 1827-1836.

501 Fischer, H., Siggaard-Andersen, M.-L., Ruth, U., Röthlisberger, R., and Wolff, E. 2007. 502 Glacial/interglacial changes in mineral dust and sea-salt records in polar ice cores: sources, 503 transport, and deposition. Rev. Geophys. 45, RG1002, doi:10.1029/2005RG000192.

504 Fitzgerald, J.W. 1991. Marine aerosols: A review. Atmos. Environ. Part A, 25, 533-546.

505 Gaiero, D.M., Probst, J.-L., Depetris, P.J., Bidart, S.M., and Leleyter, L. 2003. Iron and other 506 metals in Patagonian riverborne and windborne materials: Geochemical control and trans507 port to the southern South Atlantic Ocean. Geochim. Cosmochim. Acta 67(19), 3603-3623.

508 Genthon, C. 1992. Simulations of desert dust and sea-salt aerosol in Antarctica with a general 509 circulation model of the atmosphere. Tellus 44B, 371-389. 
510 Görlach, U. 1988. Die jahreszeitliche Variation von atmosphärischem Blei, Zink und Mangan 511 im antarktischen Küstenbereich, PhD-Thesis. Ruprecht-Karls-Universität Heidelberg, Hei512 delberg.

513 Hara, K., Osada, K., Kido, M., Matsunaga, K., Iwasaka, Y., Hashida, G., and Yamanouchi, T. 514 2005. Variations of constituents of individual sea-salt particles at Syowa station, Antarc$515 \quad$ tica. Tellus 57B, 230-246.

516 Holland, H.D. 1993. The chemistry of atmosphere and oceans, John Wiley \& Sons, 1. edition, $517 \quad$ New York, 154-157.

518 Jickells, T.D., An, Z.S., Andersen, K.K., Baker, A.R., Bergametti, G., and co-authors. 2005. 519 Global Iron Connections Between Desert Dust, Ocean Biogeochemistry, and Climate. Sci$520 \quad$ ence 308, 67-71, doi:10.1126/science.1105959.

521 Keene, W.C., Maring, H., Maben, J., Kieber, D.J., Pszenny, A.A.P. and co-authors. 2007. 522 Chemical and physical characteristics of nascent aerosol produced by bursting bubbles at a 523 model air-sea interface. J. Geophys. Res., 112, D21202, doi:10.1029/2007/JD008464.

524 König-Langlo, G., King, J.C., Pettré, P. 1998. Climatology of the three coastal Antarctic 525 stations Dumont d’Urville, Neumayer and Halley. J. Geophys. Res. 103(D9), 10 935-10 526946.

527 Kottmeier, C. and Fay, B. 1998. Trajectories in the Antarctic lower troposphere. J. Geophys. $528 \quad$ Res. 103, $10947-10959$.

529 Krinner, G. and Genthon, C. 2003. Tropospheric transport of continental tracers towards $530 \quad$ Antarctica under varying climatic conditions. Tellus 55B, 54-70.

531 Lindberg, S.E. and Harris, R.C. 1983. Water and acid soluble trace metals in atmospheric 532 particles. J. Geophys. Res. 88(C9), 5091-5100. 
533 Marion, G.M. and Farren, R.E. 1999. Mineral solubilities in the Na-K-Mg-Ca-Cl-SO ${ }_{4}-\mathrm{H}_{2} \mathrm{O}$ 534 system: A re-evaluation of the sulfate chemistry in the Spencer-Møller-Weare model. Geo$535 \quad$ chim. Cosmochim. Acta, 63, No. 9, 1305-1318.

536 Minikin, A., Legrand, M., Hall, J., Wagenbach, D., Kleefeld, C., Wolff, E., Pasteur, E.C., and 537 Ducroz, F. 1998. Sulfur-containing species (sulfate and methanesulfonate) in coastal Ant$538 \quad$ arctic aerosol and precipitation. J. Geophys. Res. 103(D9), 10,975-10,990.

539 Monahan, E.C., Spiel, D.E., and Davidson, K.L. 1986. A model of marine aerosol generation 540 via whitecaps and wave disruption. In: Oceanic Whitecaps (edited by E. Monahan and 541 G.M. Niocaill). D. Reidel, Norwell, Mass., 167-174.

542 Mosher, B.W. 1986. The atmospheric biochemistry of selenium, PhD-Thesis. University of $543 \quad$ Rhode Island, Kingston.

544 Mosher, B.W. and Duce, R.A. 1987. A global atmospheric selenium budget. J. Geophys. Res. 545 92(D11), 13,289-13,298.

546 Mosher, B.W., Duce, R.A., Prospero, J.M., Savoie, D.L. 1987. Atmospheric selenium: geo547 graphical distribution and ocean to atmosphere flux in the Pacific. J. Geophys. Res. $548 \quad$ 92(D11), 13,277-13,287.

549 Petit, J.R., Jouzel, J., Raynaud, D., Barkov, N.I., Barnola, J.-M., and co-authors. 1999. Cli550 mate and atmospheric history of the past 420,000 years from the Vostok ice core, Antarc$551 \quad$ tica. Nature 399, 429-436.

552 Piel, C. 2004. Variabilität physikalischer und chemischer Parameter des Aerosols in der ant553 arktischen Troposphäre. In: Reports on Polar and Marine Research 476 (ed. F. Riemann). 554 Alfred-Wegener-Inst. for Polar and Marine Res., Bremerhaven.

555 Planchon, F.A.M., Boutron, C.F., Barbante, C., Cozzi, G., Gaspari, V., Wolff, E.W., Ferrari, 556 C.P., and Cescon, P. 2002. Changes in heavy metals in Antarctic snow from Coats Land 557 since the mid- $19^{\text {th }}$ to the late-20 ${ }^{\text {th }}$ century. Earth Planet. Sci. Lett. 200, 207-222. 
558 Rankin, A.M., Auld, V., and Wolff, E.W. 2000. Frost flowers as a source of fractionated sea 559 salt aerosol in the polar regions. Geophys. Res. Lett. 27(21), 3469-3472.

560 Rankin, A.M., Wolff, E.W., and Martin, S. 2002. Frost flowers: Implications for tropospheric 561 chemistry and ice core interpretation. J. Geophys. Res. 107(D23), 4683, 562 doi:10.10129/2002JD002492.

563 Reinhardt, H., Kriews, M., Miller, H., Lüdke, C., Hoffmann, E., and Skole, J. 2003. Applica564 tion of LA-ICP-MS in polar ice core studies. Anal. Bioanal. Chem. 375, 1265-1275, 565 doi:10.1007/s00216-003-1793-5.

Ruth, U., Bigler, M., Röthlisberger, R., Siggaard-Andersen, M.-L., Kipfstuhl, S., and coauthors. 2007. Ice core evidence for a very tight link between North Atlantic and east Asian glacial climate. Geophys. Res. Lett. 34 L03706, doi:10.1029/2006GL02786.

Smith, J., Vance, D., Kemp, R.A, Archer, C., Toms, P., King, M., Zárate, M. 2003. Isotopic constraints on the source of Argentinean loess - with implications for atmospheric circulation and the provenance of Antarctic dust during recent glacial maxima. Earth Planet. Sci. Lett. 212, 181-196.

573 Tuncel, G., Aras, N.K., and Zoller, W.H. 1989. Temporal variations and sources of elements 574 in the South Pole Aatmosphere, 1. Nonenriched and moderately enriched elements. J. Geophys. Res. 94(D10), 13,025-13,038.

576 Turner, S.M., Harvey, M.J., Law, C.S., Nightingale, P.D., and Liss, P.S. 2004. Iron-induced 577 changes in oceanic sulfur biogeochemistry. Geophys. Res. Lett. 31, L14307, 578 doi:10.1029/2004GL020296.

579 Wagenbach, D. 1996. Coastal Antarctica: Atmospheric chemical composition and atmos580 pheric transport. In: Chemical Exchange between the Atmosphere and polar snow (ed. 581 E.W. Wolff and R.C. Bales). NATO ASI Series vol. 43, Springer-Verlag Berlin Heidel582 berg, 173-199. 
583 Wagenbach, D., Görlach, U., Moser, K., and Münnich, K.O. 1988. Coastal Antarctic aerosol: 584 the seasonal pattern of its chemical composition and radionuclide content. Tellus 40B, 426436.

586

Wagenbach, D., Ducroz, F., Mulvaney, R., Keck, L., Minikin, A., Legrand, M., Hall, J.S., and Wolff, E.W. 1998. Sea salt aerosol in coastal Antarctic regions. J. Geophys. Res. 103(D9), 10 961-10 974.

Wedepohl, K.H. 1995. The composition of the continental crust. Geochim. Cosmochim. Acta 59(7), 1217-1232.

Wen, H. and Carignan, J. 2007. Reviews on atmospheric selenium: Emission, speciation and fate. Atmos. Environ. 41, 7151-7165.

Wolff, E.W., and Suttie E.D. 1994. Antarctic snow record of southern hemisphere lead pollution. Geophys. Res. Lett. 21(9), 781-784.

Wolff, E.W., Suttie, E.D., Peel, D.A. 1999. Antarctic snow record of cadmium, copper, and zinc content during the twentieth century. Atmos. Environ. 33, 1535-1541.

Wolff, E.W., Rankin, A.M., and Röthlisberger, R. 2003. An ice core indicator of Antarctic sea ice production. Geophys. Res. Lett. 30(22), 2158, doi:10.1029/2003GL018454.

Wolff, E.W., Fischer, H., Fundel, F., Ruth, U., Twarloh, B., and co-authors. 2006. Southern Ocean sea-ice extent, productivity and iron flux over the past eight glacial cycles. Nature 440, 491-496, doi:10.1038/nature04614.

Wyputta, U. (1997). On the transport of trace elements into Antarctica using measurements at the Georg-von-Neumayer station. Tellus 49B, 93-111.

Zoller, W.H., Gladney, E.S., and Duce, R.A. 1974. Atmospheric concentration of trace metals at the South Pole. Science 183, 198-200. 
606

607 Table 1. Instrumental ICP-QMS detection limits (IDL, $\mathrm{n}=60$ ) and overall method detection 608 limits (MDL, $\mathrm{n}=49$ ) corresponding to a typical, total sampling volume of $2.0 \times 10^{4} \mathrm{~m}^{3}$. (MDL 609 for IC-analysis given in parenthesis)

610

\begin{tabular}{ccc}
\hline element & IDL & MDL \\
\hline $\mathrm{Li}\left[\mathrm{pg} \mathrm{m}{ }^{-3}\right]$ & 0.12 & 0.21 \\
$\mathrm{Na}\left[\mathrm{pg} \mathrm{m}^{-3}\right]$ & 16 & $1800(300)$ \\
$\mathrm{Mg}\left[\mathrm{pg} \mathrm{m}^{-3}\right]$ & 0.44 & $300(170)$ \\
$\mathrm{K}\left[\mathrm{pg} \mathrm{m}{ }^{-3}\right]$ & 32 & $330(100)$ \\
$\mathrm{Ca}\left[\mathrm{pg} \mathrm{m}{ }^{-3}\right]$ & 5.0 & $1300(140)$ \\
$\mathrm{Sr}\left[\mathrm{pg} \mathrm{m}^{-3}\right]$ & 0.02 & 12 \\
$\mathrm{Al}\left[\mathrm{pg} \mathrm{m}^{-3}\right]$ & 10 & 220 \\
$\mathrm{La}\left[\mathrm{pg} \mathrm{m}{ }^{-3}\right]$ & 0.005 & 0.07 \\
$\mathrm{Ce}\left[\mathrm{pg} \mathrm{m}{ }^{-3}\right]$ & 0.002 & 0.17 \\
$\mathrm{Nd}\left[\mathrm{pg} \mathrm{m}^{-3}\right]$ & 0.006 & 0.09 \\
$\mathrm{Se}\left[\mathrm{pg} \mathrm{m} \mathrm{g}^{-3}\right]$ & 2.7 & 3.1 \\
\hline
\end{tabular}

611

612

613

614 Table 2. Inter-comparison of trace elements measured by IC versus ICP-QMS: Results refer 615 to a reduced major axis regression (RMA) with slope $=\mathrm{m}, \mathrm{y}$-axis intercept $=\mathrm{b}$, regression 616 coefficient $=r^{2}$.

617

\begin{tabular}{cccc}
\hline Element & $\mathrm{m}$ & $\mathrm{b}\left[\mathrm{ng} \mathrm{m}^{-3}\right]$ & $\mathrm{r}^{2}$ \\
\hline $\mathrm{Na}$ & $1.00 \pm 0.05$ & $24 \pm 35$ & 0.52 \\
$\mathrm{~K}$ & $0.76 \pm 0.04$ & $-0.71 \pm 1.4$ & 0.43 \\
$\mathrm{Mg}$ & $1.14 \pm 0.07$ & $-5.94 \pm 6.5$ & 0.35 \\
$\mathrm{Ca}$ & $1.51 \pm 0.09$ & $-2.05 \pm 2.1$ & 0.42 \\
\hline
\end{tabular}

618 
619

620 Table 3. Summary of trace element composition of the aerosol measured during five years 621 (March 1999 through December 2003) at Neumayer Station via ICP-QMS, except for Ca and 622 K which were taken from IC-analysis. Atmospheric mean concentrations ( \pm std) refer to stan623 dard pressure (1013 hPa) and $273.16 \mathrm{~K}$.

624

\begin{tabular}{|c|c|c|c|c|c|}
\hline element & overall mean & $\begin{array}{c}\text { winter } \\
\text { Apr. to Oct. }\end{array}$ & $\begin{array}{l}\text { winter } \\
\text { range }\end{array}$ & $\begin{array}{c}\text { summer } \\
\text { Nov. to Mar. }\end{array}$ & $\begin{array}{c}\text { summer } \\
\text { range }\end{array}$ \\
\hline $\mathrm{Li}\left[\mathrm{pg} \mathrm{m}^{-3}\right]$ & $6.1 \pm 4.1$ & $6.9 \pm 4.5$ & $0.2-26.5$ & $4.9 \pm 3.1$ & $0.17-15.0$ \\
\hline $\mathrm{Na}\left[\mathrm{ng} \mathrm{m}^{-3}\right]$ & $330 \pm 340$ & $400 \pm 400$ & $41-3860$ & $220 \pm 160$ & $0.3-820$ \\
\hline $\operatorname{Mg}\left[\mathrm{ng} \mathrm{m}^{-3}\right]$ & $52 \pm 66$ & $62 \pm 80$ & $6.8-760$ & $31 \pm 22$ & $0.17-10$ \\
\hline $\mathrm{K}\left[\mathrm{ng} \mathrm{m}^{-3}\right]$ & $16 \pm 15$ & $17 \pm 13$ & $0.1^{*-6.1}$ & $14 \pm 17$ & $0.1 *-12$ \\
\hline $\mathrm{Ca}\left[\mathrm{ng} \mathrm{m}^{-3}\right]$ & $15 \pm 15$ & $19 \pm 17$ & $0.14 *-67$ & $11 \pm 8.6$ & $0.14 *-26.4$ \\
\hline $\mathrm{Al}\left[\mathrm{ng} \mathrm{m}^{-3}\right]$ & $1.0 \pm 0.7$ & $0.84 \pm 0.6$ & $0.22 *-3.2$ & $1.3 \pm 0.7$ & $0.23-3.7$ \\
\hline $\operatorname{Sr}\left[\mathrm{ng} \mathrm{m}^{-3}\right]$ & $0.29 \pm 0.27$ & $0.36 \pm 0.31$ & $0.012 *-2.6$ & $0.19 \pm 0.13$ & $0.012 *-0.53$ \\
\hline $\mathrm{La}\left[\mathrm{pg} \mathrm{m} \mathrm{m}^{-3}\right]$ & $0.86 \pm 0.7$ & $0.56 \pm 0.5$ & $0.07^{*}-3.1$ & $1.32 \pm 0.8$ & $0.07 *-5.8$ \\
\hline $\mathrm{Ce}\left[\mathrm{pg} \mathrm{m}^{-3}\right]$ & $1.6 \pm 1.3$ & $1.0 \pm 0.8$ & $0.17 *-5.5$ & $2.5 \pm 1.5$ & $0.17 *-10.5$ \\
\hline $\mathrm{Nd}\left[\mathrm{pg} \mathrm{m^{-3 } ]}\right.$ & $0.7 \pm 0.6$ & $0.47 \pm 0.45$ & $0.09 *-2.7$ & $1.1 \pm 0.6$ & $0.09 *-4.4$ \\
\hline $\mathrm{Se}\left[\mathrm{pg} \mathrm{\textrm {m } ^ { - 3 } ]}\right.$ & $19 \pm 18$ & $16 \pm 11$ & $3.1 *-82$ & $25 \pm 24$ & $3.1 *-160$ \\
\hline
\end{tabular}


628 Table 4. Al, La, Na, and Se concentrations ( \pm std) measured in Antarctic aerosol samples.

629

\begin{tabular}{|c|c|c|c|c|}
\hline element & winter & summer & sampling period & site $^{\mathrm{a}}$ \\
\hline $\begin{array}{c}\mathrm{Al} \\
{\left[\mathrm{pg} \mathrm{m}^{-3}\right]}\end{array}$ & $\begin{array}{c}- \\
300 \pm 40 \\
320 \pm 110 \\
- \\
9470^{b} \\
840 \pm 600\end{array}$ & $\begin{array}{c}570 \pm 170 \\
830 \pm 410 \\
730 \pm 240 \\
194 \pm 19 \\
13290^{\mathrm{b}} \\
1270 \pm 700\end{array}$ & $\begin{array}{c}10 / 1970 \\
1971 / 75 / 76 / 78 \\
2 / 1979-11 / 1983 \\
12 / 1984-02 / 1985 \\
1985-1988 \\
3 / 1999-12 / 2003\end{array}$ & $\begin{array}{c}\text { SP (Zoller et al., 1974) } \\
\text { SP (Cunningham \& Zoller, 1981) } \\
\text { SP (Tuncel et al., 1989) } \\
\text { AP (Dick, 1991) } \\
\text { AP (Artaxo et al., 1992) } \\
\text { NM, this study }\end{array}$ \\
\hline $\begin{array}{c}\mathrm{La} \\
{\left[\mathrm{pg} \mathrm{m}^{-3}\right]}\end{array}$ & $\begin{array}{c}- \\
<2 \\
0.43 \pm 0.11 \\
0.56 \pm 0.5\end{array}$ & $\begin{array}{c}0.51 \pm 0.37 \\
0.78 \pm 0.25 \\
0.56 \pm 0.21 \\
1.32 \pm 0.8\end{array}$ & $\begin{array}{c}10 / 1970 \\
1971 / 75 / 76 / 78 \\
2 / 1979-11 / 1983 \\
3 / 1999-12 / 2003\end{array}$ & $\begin{array}{c}\text { SP (Zoller et al., 1974) } \\
\text { SP (Cunningham \& Zoller, 1981) } \\
\text { SP (Tuncel et al., 1989) } \\
\text { NM, this study }\end{array}$ \\
\hline $\begin{array}{c}\mathrm{Na} \\
{\left[\mathrm{ng} \mathrm{m}^{-3}\right]}\end{array}$ & $\begin{array}{c}- \\
40 \pm 31 \\
31 \pm 14 \\
869.9^{b} \\
- \\
400 \pm 400\end{array}$ & $\begin{array}{c}7.2 \pm 3.8 \\
5.1 \pm 1.7 \\
8.7 \pm 3.2 \\
1046.2^{b} \\
27.6 \pm 0.4 \\
220 \pm 160\end{array}$ & $\begin{array}{c}10 / 1970 \\
1971 / 75 / 76 / 78 \\
2 / 1979-11 / 1983 \\
1985-1988 \\
12 / 1984-02 / 1985 \\
3 / 1999-12 / 2003\end{array}$ & $\begin{array}{c}\text { SP (Zoller et al., 1974) } \\
\text { SP (Cunningham \& Zoller, 1981) } \\
\text { SP (Tuncel et al., 1989) } \\
\text { AP (Artaxo et al., 1992) } \\
\text { AP (Dick, 1991) } \\
\text { NM, this study }\end{array}$ \\
\hline $\begin{array}{c}\mathrm{Se} \\
{\left[\mathrm{pg} \mathrm{m}^{-3}\right]}\end{array}$ & $\begin{array}{c}- \\
6.9 \pm 2.7 \\
4.8 \pm 0.8 \\
118^{\mathrm{b}} \\
16 \pm 11\end{array}$ & $\begin{array}{l}5.6 \pm 1.2 \\
6.3 \pm 6 \\
8.4 \pm 1.6 \\
122^{\mathrm{b}} \\
25 \pm 24\end{array}$ & $\begin{array}{c}10 / 1970 \\
1971 / 75 / 76 / 78 \\
2 / 1979-11 / 1983 \\
1 / 1983-12 / 1984 \\
3 / 1999-12 / 2003\end{array}$ & $\begin{array}{c}\text { SP (Zoller et al., 1974) } \\
\text { SP (Cunningham \& Zoller, 1981) } \\
\text { SP (Tuncel et al., 1989) } \\
\text { AP (Artaxo et al., 1992) } \\
\text { NM, this study }\end{array}$ \\
\hline
\end{tabular}

$630 \quad{ }^{\mathrm{a}} \mathrm{AP}=$ Antarctic Peninsula, $\mathrm{SP}=$ South Pole, $\mathrm{NM}=$ Neumayer

$631{ }^{\mathrm{b}}$ sum of fine and coarse mode 
633

634

635

636

637

638

639

640

641

642

643

644

645

646

647

648

649

650

651

652

653

654

655

656

657

658

\section{FIGURES}

Fig. 1: (a) Mean element enrichment factors with respect to earth crust $\left(\mathrm{EF}_{\text {crust }}\right)$ and (b) sea salt composition $\left(\mathrm{EF}_{\mathrm{sS}}\right)$ of Neumayer aerosol samples dissected for summer (November through March) and winter (April through October), respectively.

Fig. 2: Atmospheric Na, Li, and Sr concentrations measured at Neumayer Station at weekly time resolution. The grey bars mark the method detection limits.

Fig. 3: Same as Figure 2 but for Al, La, Ce, and Nd.

Fig. 4: Pie diagram of the aerosol composition (weight percent referring to the sum of the measured species) at Neumayer during winter and summer, respectively.

Fig. 5: Mean annual cycle of major mass fractions in Neumayer aerosol samples: Sea salt (circles), biogenic sulfur (i.e. the sum of MS and nss- $\mathrm{SO}_{4}{ }^{2-}$, drawn line), and mineral dust (diamonds) portion.

Fig. 6: Seasonality of monthly concentration mean of sea salt (Na) and mineral dust (La) reference elements. Values correspond to 5 years of observation (i.e. about 20 samples per month). Error bars indicate the respective standard deviation.

Fig. 7: Time series of wind velocity at Neumayer during the sampling period displayed in the same temporal resolution as filter sampling (seven days, thin line), and 6 points moving average (bold grey line). 
660 Fig. 8: Notched box plots for enrichment factors respecting standard mean ocean water com-

661 position for the sea salt portion of $\mathrm{Li}, \mathrm{K}, \mathrm{Mg}$, $\mathrm{Ca}$, and $\mathrm{Sr}$. Lines in the middle of the boxes

662 represent sample medians (values are given aside), lower and upper lines of the boxes are the

$66325^{\text {th }}$ and $75^{\text {th }}$ percentiles, whiskers show the range of the sample values while outliers are 664 marked by “+” signs. The widths of the notches indicate the confidence interval of the me665 dian.

666

667 Fig. 9: Double-logarithmic plot of ssLi, ssMg, and ssSr vs. ssNa. Bold grey lines represent 668 the relation for standard mean ocean water.

669

670 Fig. 10: Time series of Se and MS (shifted y-axis) concentrations measured at Neumayer.

671 The grey bar marks the method detection limit for Se.

672 

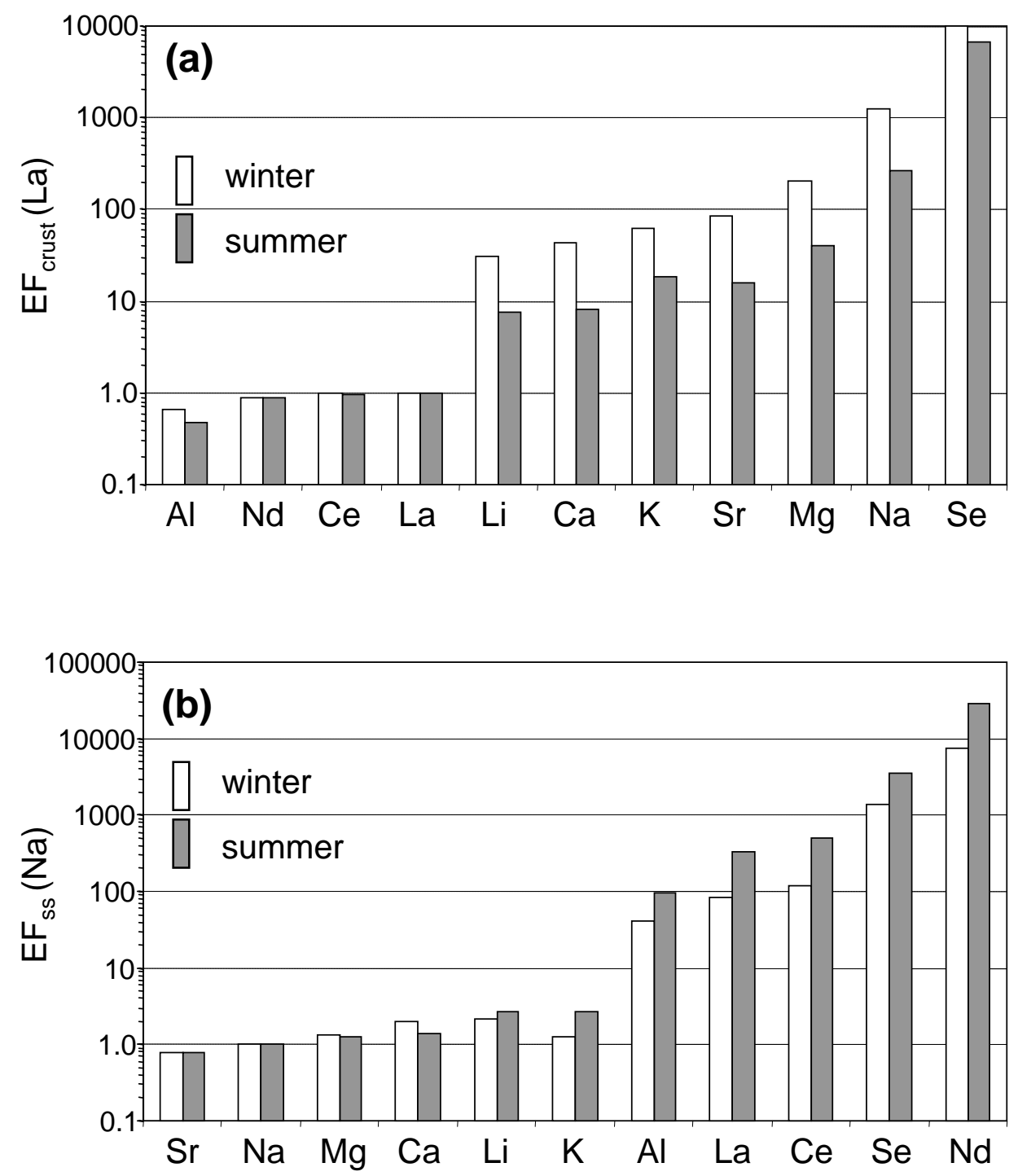

Figure 1: (a) Mean element enrichment factors with respect to earth crust $\left(\mathrm{EF}_{\text {crust }}\right)$ and (b) sea salt composition $\left(\mathrm{EF}_{\mathrm{ss}}\right)$ of Neumayer aerosol samples dissected for summer (November through March) and winter (April through October), respectively. 

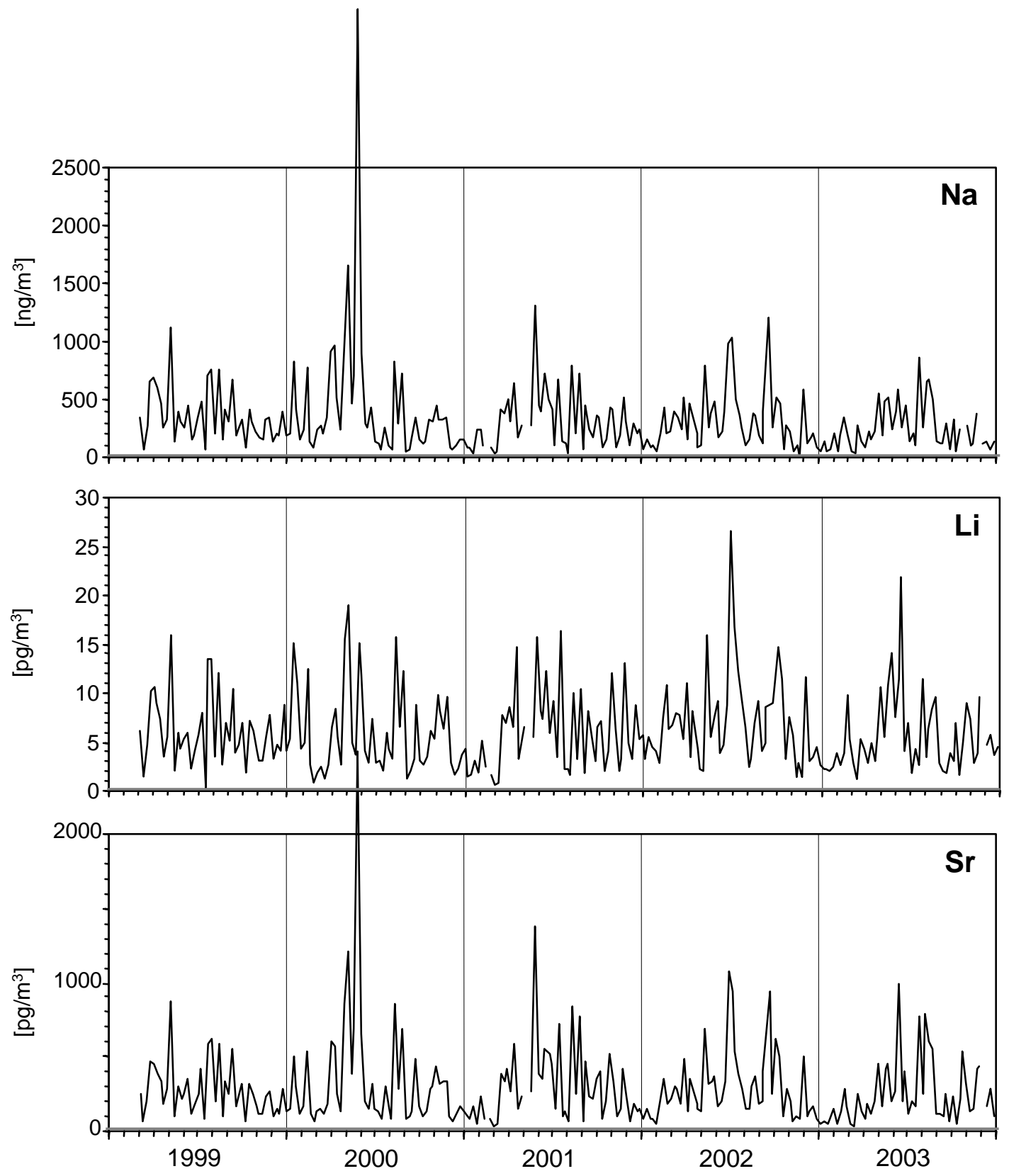

Figure 2: Atmospheric $\mathrm{Na}, \mathrm{Li}$, and $\mathrm{Sr}$ concentrations measured at Neumayer Station at weekly time resolution. The grey bars mark the method detection limits. 

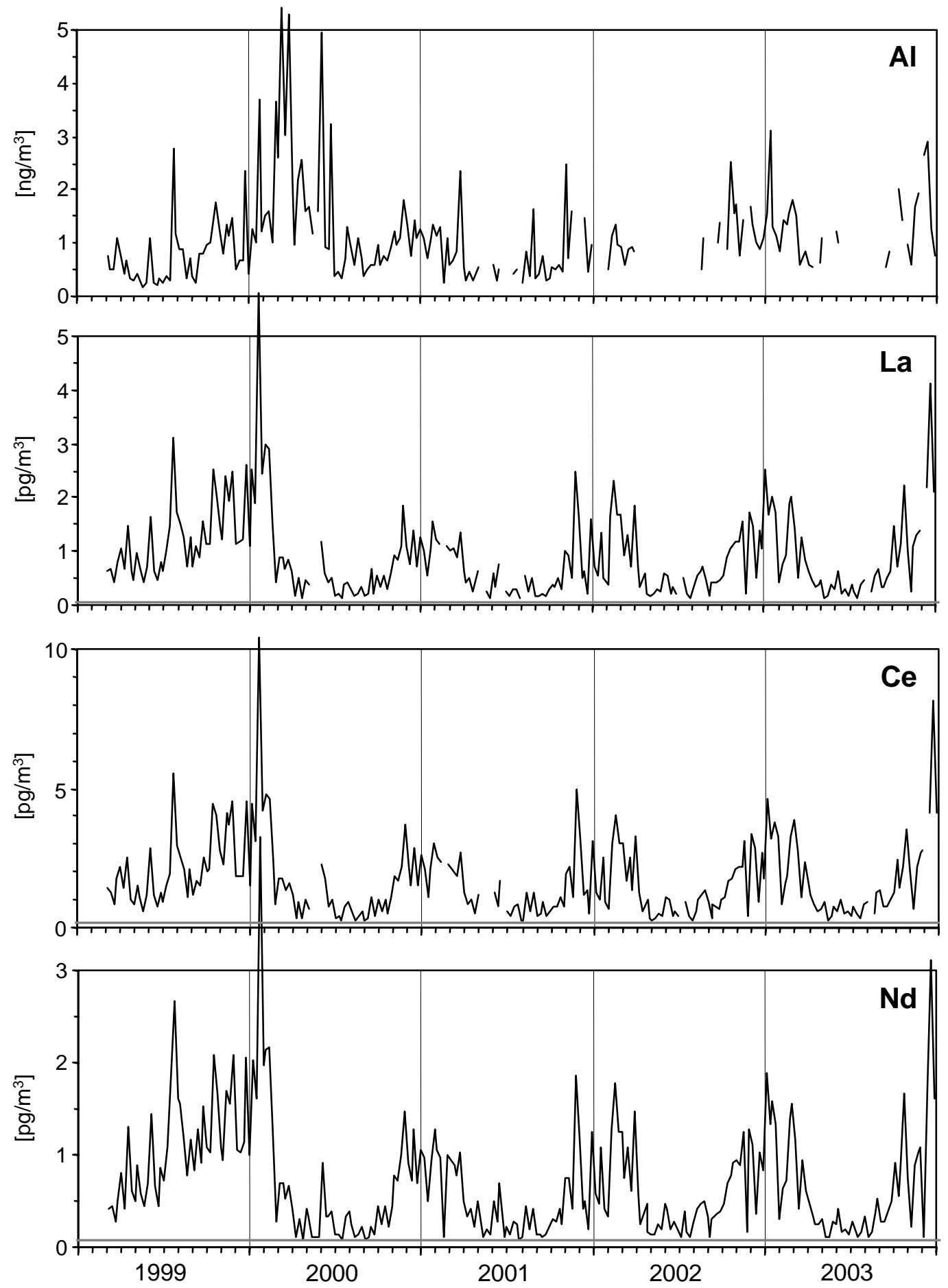

Figure 3: Same as Figure 2 but for $\mathrm{Al}, \mathrm{La}, \mathrm{Ce}$, and $\mathrm{Nd}$. 
Aerosol composition winter

(April-October)

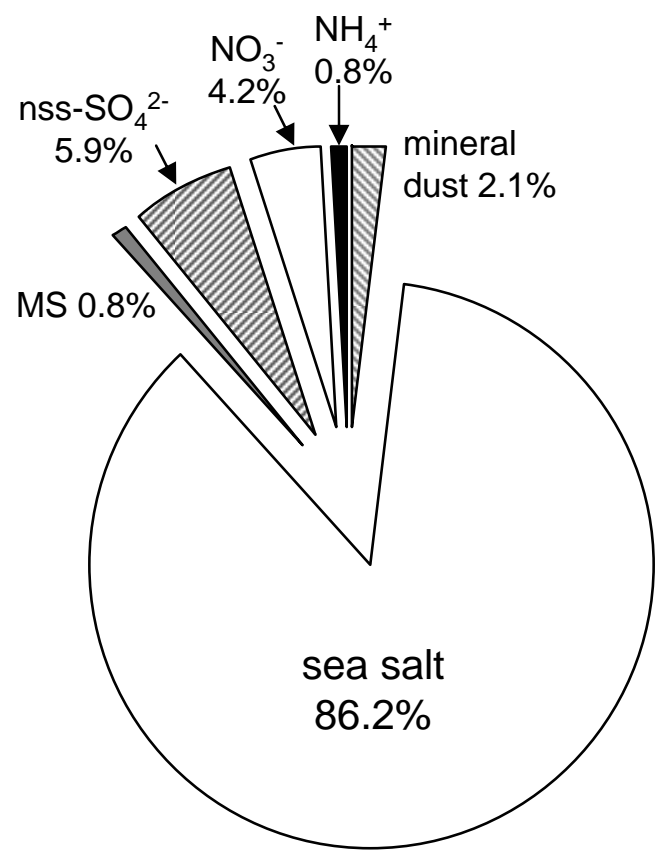

Aerosol composition summer

(November-March)

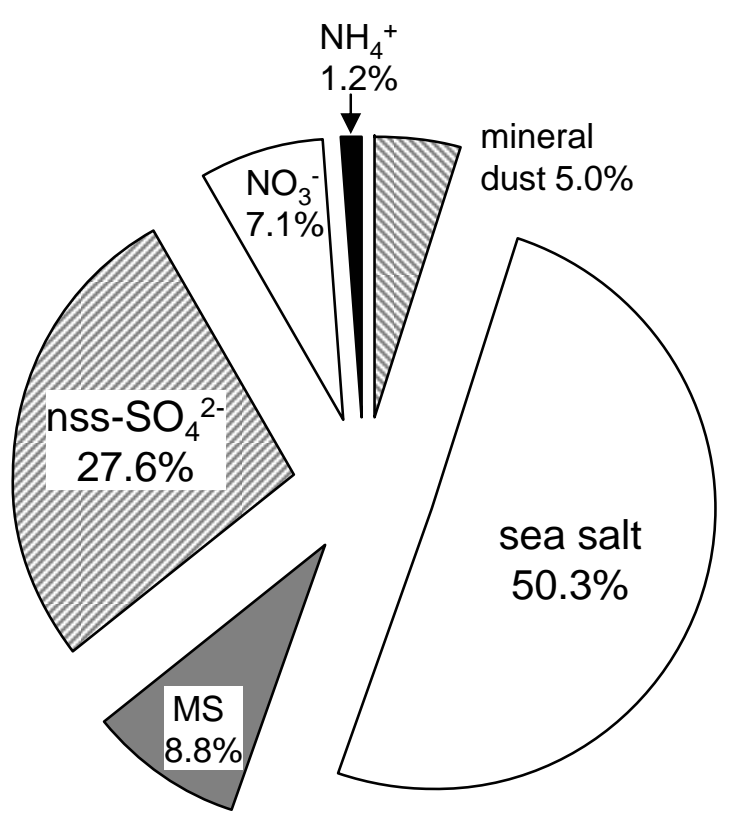

Figure 4: Pie diagram of the aerosol composition (weight percent referring to the sum of the measured species) at Neumayer during winter and summer, respectively. 


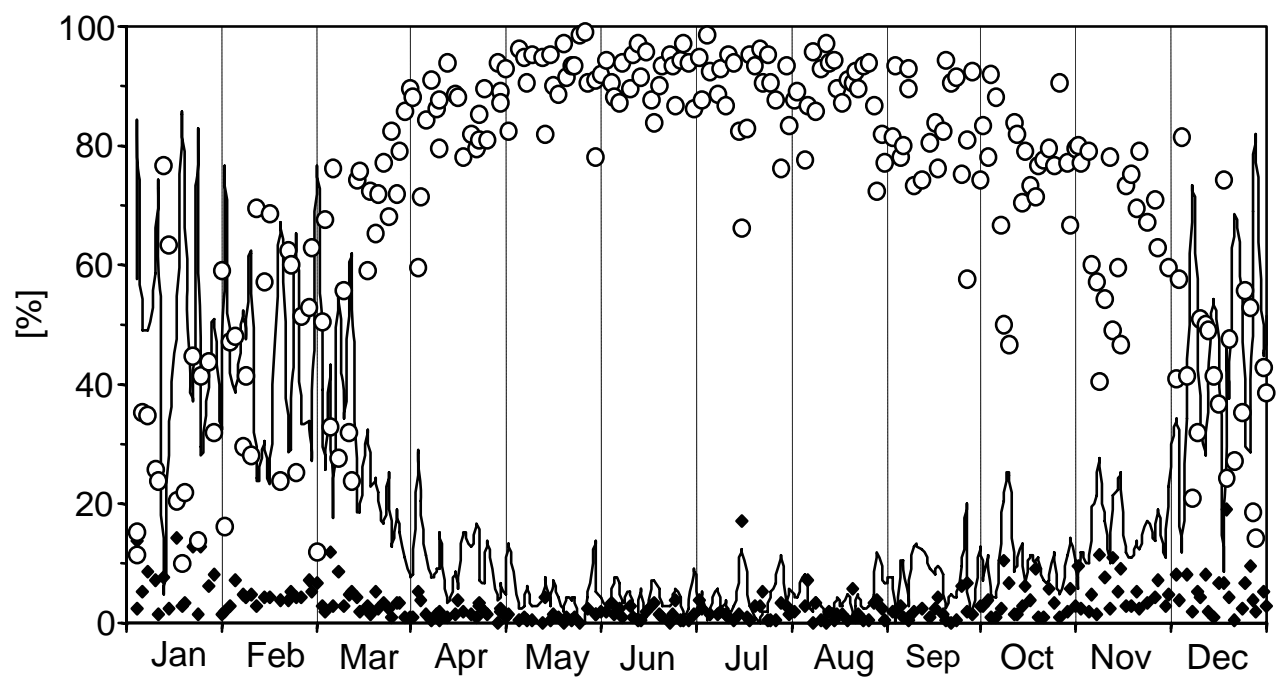

Figure 5: Mean annual cycle of major mass fractions in Neumayer aerosol samples: Sea salt (circles), biogenic sulfur (i.e. the sum of MS and nss- $\mathrm{SO}_{4}{ }^{2-}$, drawn line), and mineral dust (diamonds) portion. 

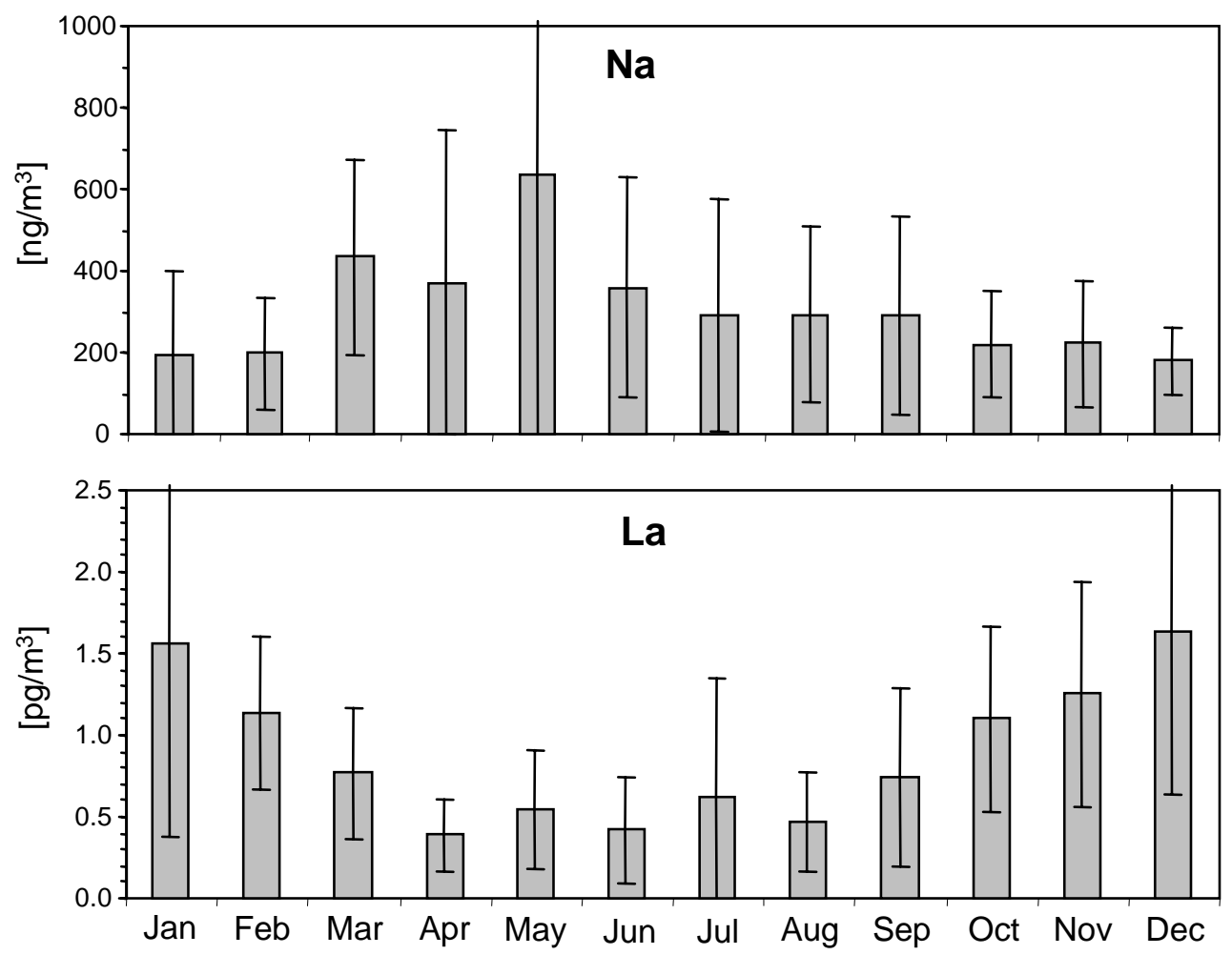

Figure 6: Seasonality of monthly concentration means of sea salt $(\mathrm{Na})$ and mineral dust (La) reference elements. Values correspond to 5 years of observation (i.e. about 20 samples per month). Error bars indicate the respective standard deviation. 


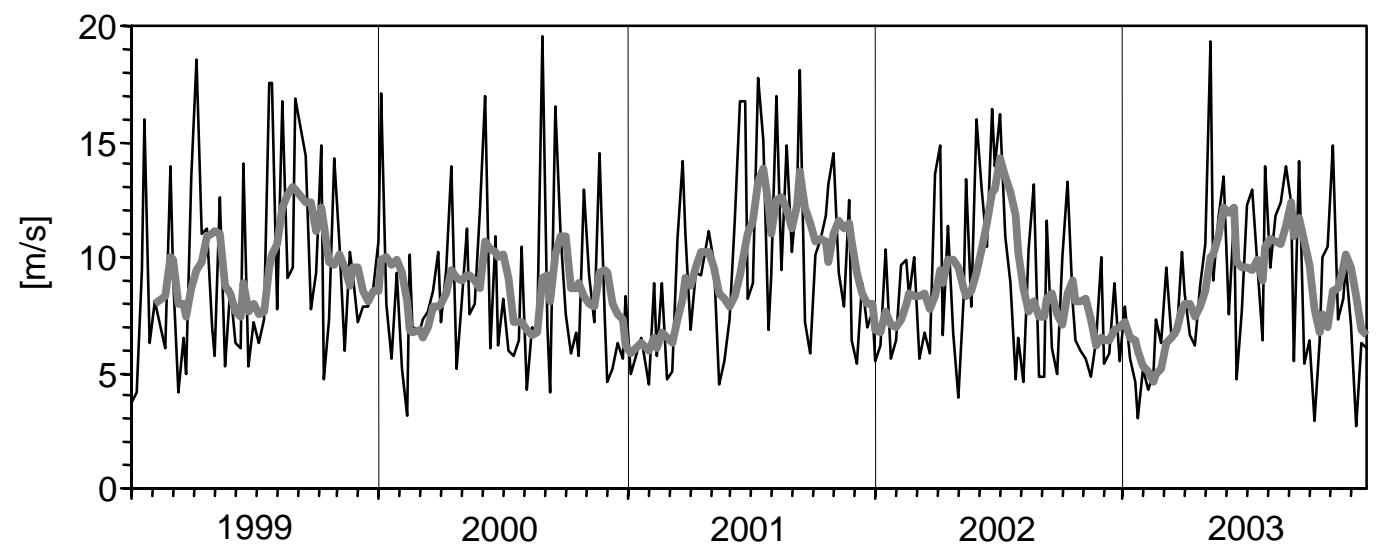

Figure 7: Time series of wind velocity at Neumayer during the sampling period displayed in the same temporal resolution as filter sampling (seven days, thin line), and 6 points moving average (bold grey line). 


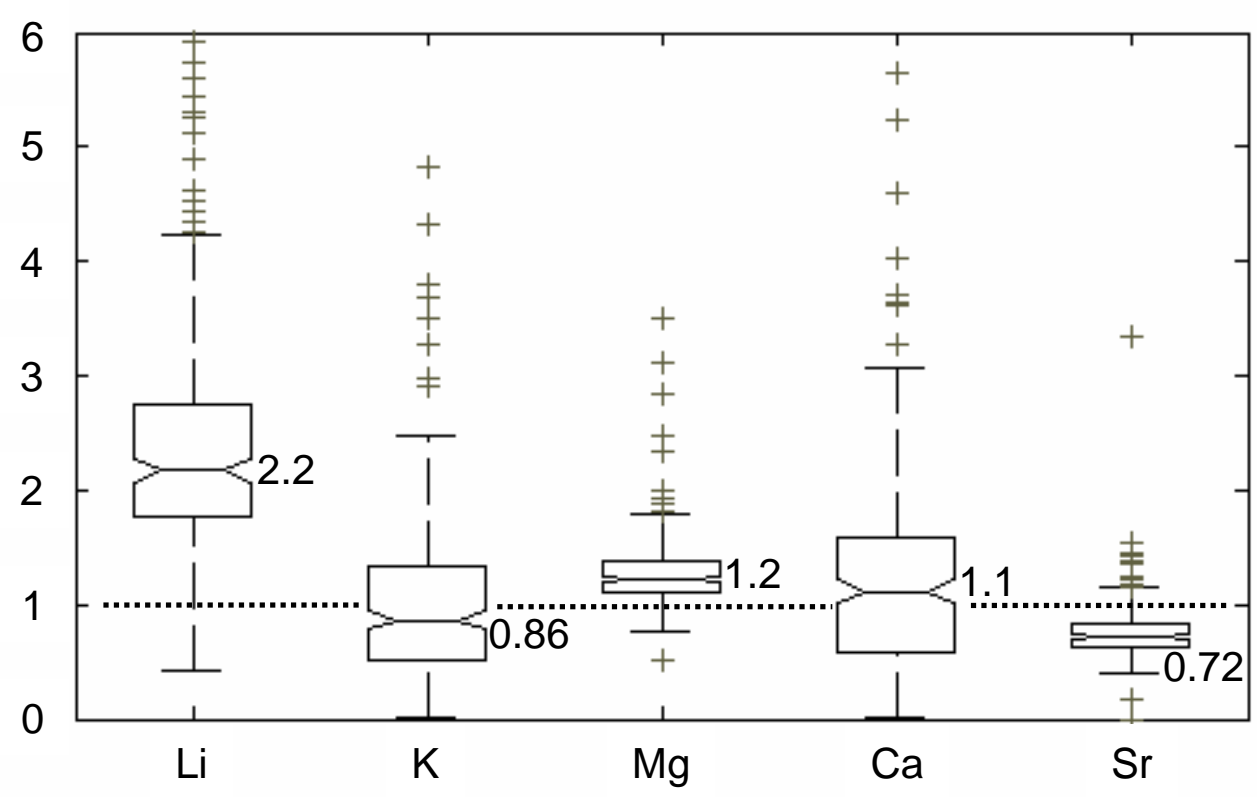

Figure 8: Notched box plots for enrichment factors respecting standard mean ocean water composition for the sea salt portion of $\mathrm{Li}, \mathrm{K}, \mathrm{Mg}, \mathrm{Ca}$, and $\mathrm{Sr}$. Lines in the middle of the boxes represent sample medians (values are given aside), lower and upper lines of the boxes are the $25^{\text {th }}$ and $75^{\text {th }}$ percentiles, whiskers show the range of the sample values while outliers are marked by “+” signs. The widths of the notches indicate the confidence interval of the median. 


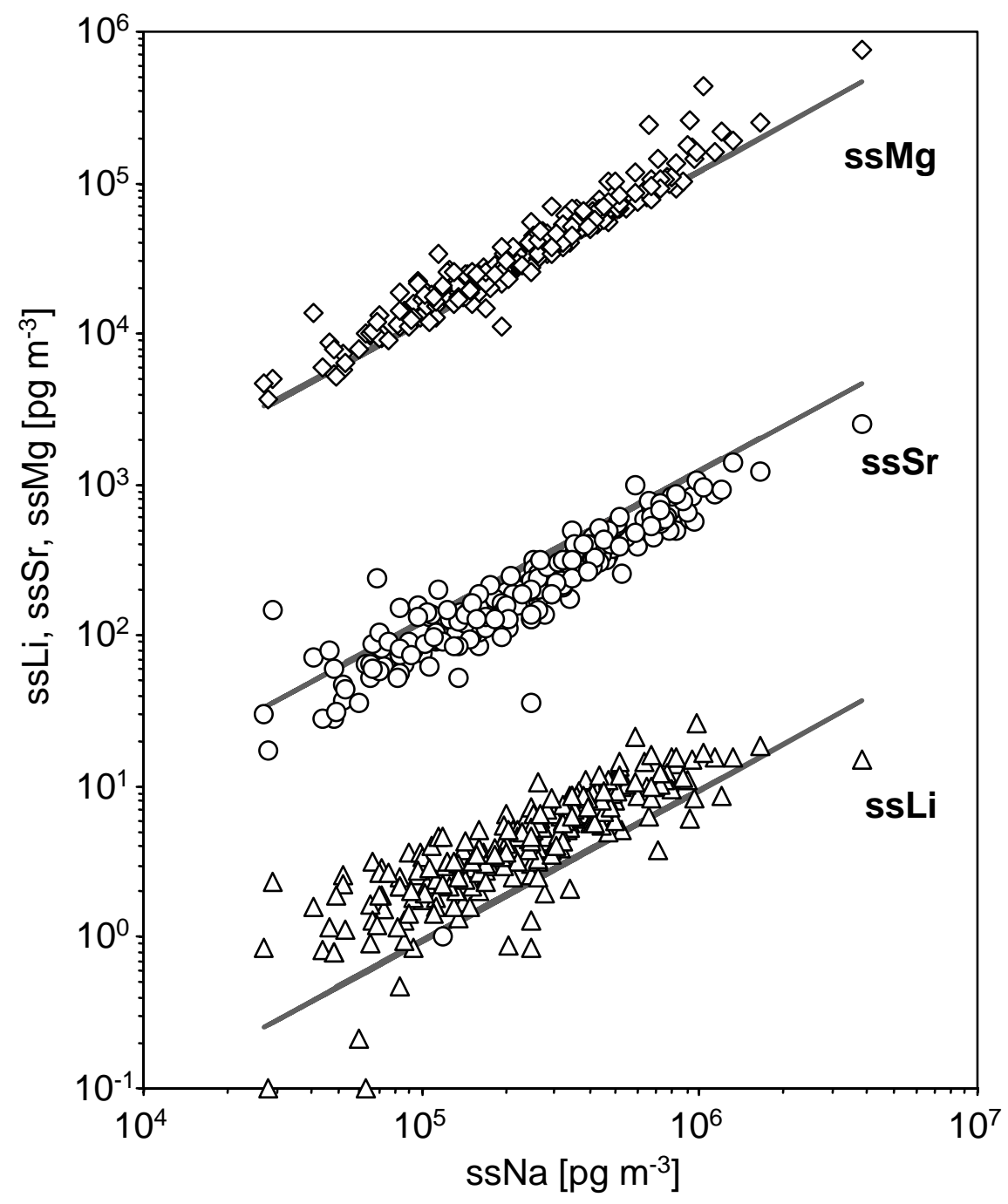

Figure 9: Double-logarithmic plot of ssLi, ssMg, and ssSr vs. ssNa. Bold grey lines represent the relation for standard mean ocean water. 


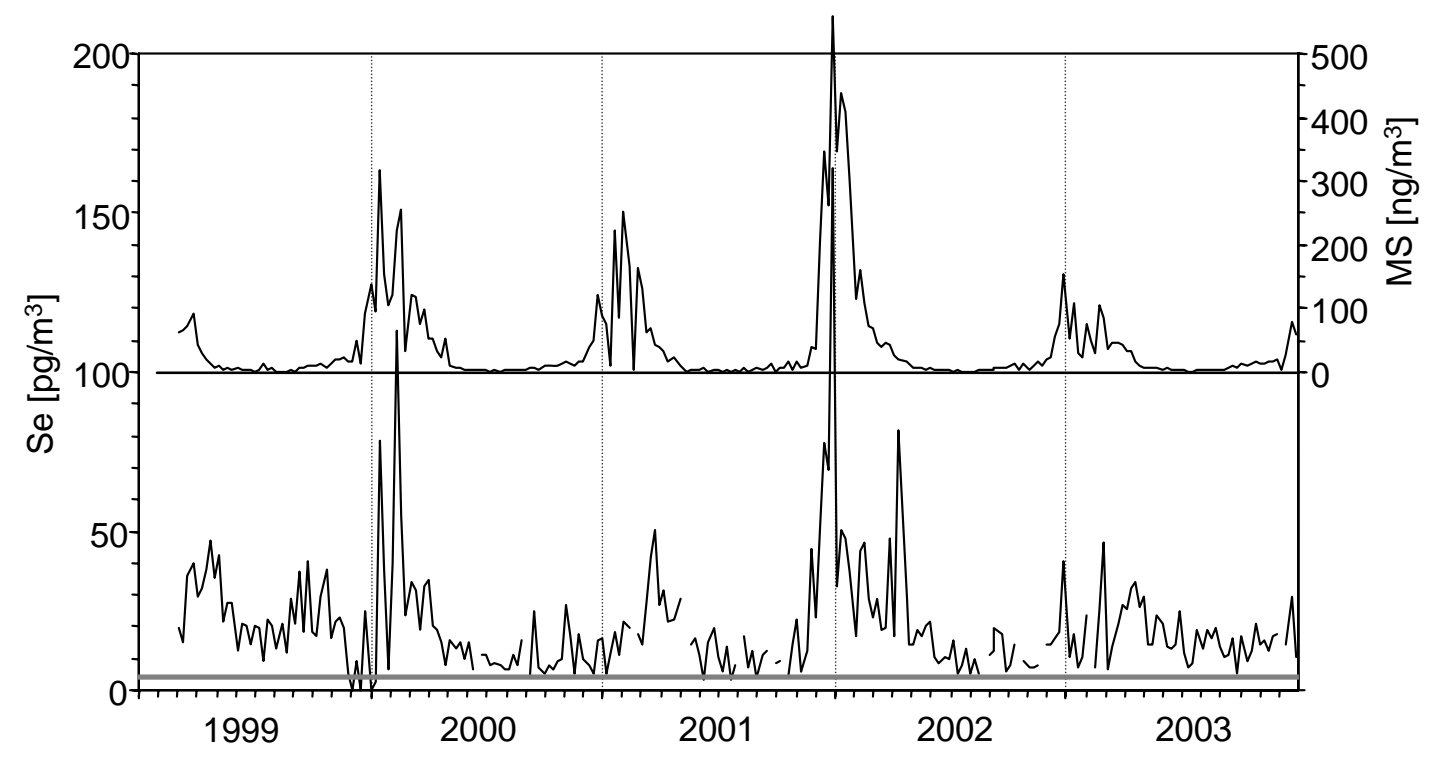

Figure 10: Time series of Se and MS (shifted y-axis) concentrations measured at Neumayer. The grey bar marks the MDL for Se. 